\title{
Motivations for Coopetition Strategies between Banks and Fintechs
}

\author{
Cristina FONSECA \\ School of Economics and Management of University of Porto, Portugal \\ isabel.cristina.fs@hotmail.com \\ Raquel MENESES \\ School of Economics and Management of University of Porto, Portugal \\ raquelm@fep.up.pt
}

\begin{abstract}
The aim of this study is to identify the main motivations for the formation of strategic coopetitive partnerships between Banks and Fintechs. In this sense, an exploratory qualitative analysis was performed using semi-structured interviews. Following the triangulation between literature review, primary sources (interviews) and secondary sources (news and relevant documentation), the analysis of the results was performed using the Systematic Combination approach. The results led to the conclusion that the "clients" factor, materialized in the will to respond to their new demands, through value creation, is the main motivation for both institutions to establish strategic alliances. This study filled the literature gaps regarding the identification of the main motivations to form coopetitive strategic alliances between Banks and Fintechs: banks need the Fintechs' technological know-how, their flexibility in the processes and the fact that Fintech operate in specific niches; Fintechs need banks' market knowledge and their scale. Together they can answer in a better way new customer demand. This investigation is limited by the lack of tangible identification of existing Fintechs; and also because of qualitative analysis lack of quantitative confirmation.
\end{abstract}

Keywords: banks, coopetition, fintech, financial innovation, financial sector, motivations.

\section{Introduction}

The financial sector is currently undergoing a paradigm shift process, which is the result, on the one hand, of new consumer demands, which are increasingly focused on personalizing financial products and services; and, on the other hand, it is the result of the changes accelerated by globalization itself, with emphasis on the emergence of new technologies and new business models based on digitalization.

Disruptive digitalization in the financial services industry has been carried out by companies in the technological area, namely Fintech (Kawai, 2016; Lee \& Shin, 2018).

Due to the peculiar characteristics of the current world, one of the possible strategies adopted is the strategic alliance between competitors, also called coopetition, a situation in which organizations cooperate and compete simultaneously (Bengtsson \& Kock, 2014).

Several authors have analyzed the concept of coopetition (Bengtsson, Johansson, Näsholm \& Raza-Ullah, 2013; Bouncken, Gast, Kraus \& Bogers, 2015; Dorn, Schweiger \& Albers, 2016; Walley, 2007), in some sectors of activity, such as: tourism (Della Corte \& Aria, 2016; Romero, Porto-Gómez \& Zabala-Iturriagagoitia, 2018); health (Bouncken \& Fredrich, 2016; Bouncken, Clauß \& Fredrich, 2016; Broek, Boselie \& Paauwe, 2018); telecommunications (Yami \& Nemeh, 2014); technology (Lee, Park, \& Lee, 2017; Ritala \& Hurmelinna-Laukkanen, 2009); video games (Chiambaretto, Massé \& Mirc, 2019; Klimas \& Czakon, 2018); multinational companies (Luo, 2005, 2007; Estrada, Faems \& de Faria, 2016).

The financial sector has been left out of these studies. In this context, Schmidt, Drews and Schirmer (2018) suggest more research on the reasons that motivate Banks and Fintechs to 
collaborate; and Holotiuk, Klus, Lohwasser and Moormann (2018) also warn of the lack of studies that specify the individual motivations of Banks and Fintech to form strategic alliances.

According to a study by PWC (Global FinTech Report 2017), 82\% of financial institutions already established on the market expect to increase alliances with Fintech over the next three to five years, with the majority of study participants $(88 \%)$ concerned about the possibility that part of your business may be at risk, with the entry of Fintech, in the financial sector.

PICBE | 283

Another study, the "World FinTech Report 2018" found that $75.5 \%$ of Fintech intend to collaborate with the incumbent, $18.1 \%$ prefer to compete individually, and the rest $(6.4 \%)$ have as main objective to be acquired by other Fintech or traditional financial institutions.

In view of this scenario and in order to fill the gaps in the literature, we intend to investigate the motivations that lead to the adoption of coopetition strategies in the financial sector, more specifically, with regard to the relationship between banking institutions and technological entities operating in the financial sector, Fintech.

We opted by an exploratory qualitative analysis, using triangulation between data from primary sources (interviews semi-structured) and data from secondary sources (news and documents).

\section{Literature review}

The financial sector has undergone profound changes, with emphasis on the adoption of new digital technologies, which impact both products, services and processes, as well as business models. In the last decades, new companies that focus on the provision of financial services, based on technological solutions, have appeared continuously. The traditional banking model thus evolves towards a segmented model, with the presence of different actors with differentiating and innovative offers, such as those called Fintech.

These entities use technology for banking services, payments, financial data analysis, capital markets and personal financial management. These new technologies allow customers to consult, on a single platform, information from several bank accounts, even if they belong to different financial institutions.

The Fintech, which often manifest themselves through the breakdown of the value chain of financial institutions, intended to not only have access to the banks' customer bases, but above all, attract more traditional customers by offering personalized services for your needs; this being one of the main differences between the banking and Fintech's business models. On the one hand, banks are characterized by their credibility with customers, by the security and robustness of services provided, but also by bureaucracy and slow processes. For their part, Fintech represents the simplicity and agility of the processes, together with a digital and transparent experience.

Holotiuk, Klus, Lohwasser and Moormann (2018) conclude that, in this context, Banks provide Fintech with support in regulatory matters and access to customer bases; on the other hand, Fintech promote a more individualized and informed contact with the customer.

So, in this new context, banks lose exclusivity and competitive advantage with customers, but, on the other hand, Fintech depend on the bank's customer portfolio; giving rise to a situation of simultaneous cooperation and competition between both. This coopetition emerges as a strategy that combines the benefits of cooperation and competition in order to fill the gaps of each.

\section{Coopetition}

Bouncken, Gast, Kraus and Bogers (2015) refer to coopetition as a paradoxical strategic process, in which economic agents create value through cooperative relationships, while simultaneously 
competing to capture part of the value created. The adoption of coopetition strategies therefore allows companies to enhance their competitive advantages (Ritala \& Hurmelinna-Laukkanen, 2009), as a result of the development of products or services that without the participation of the coopetition partner would be almost impossible to produce (Dvorsky et al., 2019; Walley, 2007). "The best partner for your company, a strategic alliance is, for the time, their strongest competitors" (Gnyawali \& Park, 2009, p. 312), since, as a rule, a competitor shares the same threats and opportunities and, therefore, it can have the complementary resources to its competitors.

\section{Motivations for coopetition between Banks and Fintech.}

The main general motivations for strategic alliances between competitors are the access to resources or to new markets (segments) and knowledge sharing (Bengtsson \& Kock, 2014; RazaUllah, Bengtsson \& Kock, 2014); the possibility of developing new products and new market standards (Radu, 2010); the incorporation and development of new technologies (Gnyawali \& Park, 2011); improving the company's position and competitive advantage (Ritala, 2012; Ritala \& Hurmelinna-Laukkanen, 2009; Rusko, 2011); reduction of associated risks (Cygler, Sroka, Solesvik \& Debkowska, 2018) and the will to develop innovation (Gast, Filser, Gundolf \& Kraus, 2015; Gnyawali \& Park, 2011).

With regard to strategic partnerships between Banks and Fintech, the literature highlights, from the perspective of banking institutions, the increasing digitization (Klus, Lohwasser \& Schwienbacher, 2018), more specifically, digital innovation (Holotiuk, Klus, Lohwasser \& Moormann, 2018), as the main motivation for establishing partnerships with Fintechs; on the other hand, in the case of technological entities, the literature highlights the possibility of obtaining economies of scale (Stewart \& Jürjens, 2018; Jakšič \& Marinc, 2019), as one of the main objectives, for the formation of strategic alliances with Banks.

Finally, what also motivates both sides to establish in partnerships is the factor "customers", materializad the in the answer to new requirements and value creation (Holotiuk, Klus, Lohwasser \& Moormann, 2018; Walley, 2007), considering, therefore, a common motivation for Banks and Fintech's.

One of the generic motivations of strategic alliances between competitors is to fight a stronger common competitor (Cygler, Sroka, Solesvik \& Debkowska, 2018). Thus, the case of BigTech may also sets a plausible reason for the union Banks and Fintech, in order to respond to the threat posed by these large entities.

On the one hand, Fintech benefit from the stability of banks and they benefit from the digital and innovative capabilities of Fintech (Bussmann, 2017), as well as their strategies with a primary focus on customers. These are considered non-traditional competitors of banks, with technological offers that aim to innovate, in a disruptive way, financial technology solutions.

Banks must therefore devise a strategy in order to take advantage of new technological opportunities and minimize possible threats, if they intend to survive in the competitive environment that will be established with the effective entry of Fintech into the financial sector. In recent years, banks have accepted the importance of new technologies, associated with the banking system, but mainly realized the importance of creating alliances with Fintech.

The current context of digitalization and globalization promotes the adoption of new and differentiating strategies, as well as the establishment of new strategic alliances, which highlight the strengths, covering the weaknesses of each party involved; that is, the new context promotes the adoption of coopetitive strategies. 


\section{Initial framework}

In the literature, there are some motivations for forming strategic alliances between competitors (coopetition) (Table 1). Among the general motivations are possible access to resources and new markets; the development of new products and new technologies; increasing competitive advantage; knowledge sharing; risk reduction and the will to develop innovation. Regarding the critical factors for the formation of strategic alliances, the literature highlighted, on the banks' side, digitization, more specifically, digital innovation; and on the Fintech side, economies of scale.

\section{Table 1 - Theoretical Categories}

\begin{tabular}{|c|c|c|}
\hline \multicolumn{3}{|c|}{ General Motivations } \\
\hline Category & Definition & Source \\
\hline $\begin{array}{l}\text { Access to new } \\
\text { markets or market } \\
\text { segments }\end{array}$ & $\begin{array}{l}\text { Accessing new markets (segments), as a rule, implies costs and } \\
\text { risks, therefore, there are companies that opt for strategic } \\
\text { partnerships, with competing, but consolidated companies, in } \\
\text { the market they intend to access. }\end{array}$ & \multirow{3}{*}{$\begin{array}{l}\text { Bengtsson \& Kock (2014) } \\
\text { Bouncken \& Kraus (2013) } \\
\text { Raza-Ullah, Bengtsson \& } \\
\text { Kock (2014) }\end{array}$} \\
\hline $\begin{array}{ll}\text { Access } & \text { to } \\
\text { Resources } & \end{array}$ & $\begin{array}{l}\text { Access to additional resources that can potentially fill the gaps } \\
\text { in organizations involved in the partnership. }\end{array}$ & \\
\hline $\begin{array}{l}\text { Knowledge } \\
\text { sharing }\end{array}$ & $\begin{array}{l}\text { Promote exchanges of resources and knowledge in various } \\
\text { areas. }\end{array}$ & \\
\hline $\begin{array}{l}\text { Development of } \\
\text { new products and } \\
\text { new market } \\
\text { standards }\end{array}$ & $\begin{array}{l}\text { Combining complementary knowledge and resources, in order } \\
\text { to develop new products and/or new market standards. }\end{array}$ & Radu (2010) \\
\hline $\begin{array}{lr}\text { Incorporate } & \text { and } \\
\text { develop } & \text { new } \\
\text { technologies } & \\
\end{array}$ & $\begin{array}{l}\text { In the current context of increasing digitalization, new } \\
\text { technologies have promoted the creation of strategic alliances } \\
\text { between competitors. }\end{array}$ & Gnyawali \& Park (2011) \\
\hline $\begin{array}{l}\text { Improve the } \\
\text { company's } \\
\text { position and } \\
\text { competitive } \\
\text { advantage }\end{array}$ & $\begin{array}{l}\text { Potential increase in competitive advantage, within the scope } \\
\text { of the market in which the organizations involved in the } \\
\text { partnership, operate. }\end{array}$ & $\begin{array}{l}\text { Ritala }(2012) \\
\text { Ritala \& Hurmelinna- } \\
\text { Laukkanen (2009) } \\
\text { Rusko (2011) }\end{array}$ \\
\hline Risk reduction & $\begin{array}{l}\text { In different markets, both incumbents and new entrants may } \\
\text { face different risks and, by establishing strategic partnerships, } \\
\text { with each other, they may eventually reduce those risks. }\end{array}$ & $\begin{array}{l}\text { Cygler, Sroka, Solesvik \& } \\
\text { Debkowska (2018) }\end{array}$ \\
\hline $\begin{array}{l}\text { Willingness to } \\
\text { develop } \\
\text { Innovation }\end{array}$ & $\begin{array}{l}\text { Strategic partnerships between competitors can stem from the } \\
\text { willingness of both parties to develop innovations, within the } \\
\text { scope of the market in which they operate. }\end{array}$ & $\begin{array}{l}\text { Gast, Filser, Gundolf \& } \\
\text { Kraus (2015) } \\
\text { Gnyawali \& Park (2011) }\end{array}$ \\
\hline \multicolumn{3}{|c|}{ Banks' Motivation } \\
\hline Category & Definition & Source \\
\hline $\begin{array}{l}\text { Digitization } \\
\text { Digital innovation }\end{array}$ & $\begin{array}{l}\text { The current context, predominant in new digital technologies, } \\
\text { constitutes a motivation of the incumbent financial institutions, } \\
\text { to ally themselves with the new technological entrants, in order } \\
\text { to fill certain gaps, related to their technological and digital } \\
\text { capabilities. }\end{array}$ & $\begin{array}{l}\text { Klus, Lohwasser \& } \\
\text { Schwienbacher (2018) } \\
\text { Holotiuk, Klus, Lohwasser } \\
\text { \& Moormann (2018) }\end{array}$ \\
\hline \multicolumn{3}{|c|}{ Fintech' Motivation } \\
\hline Category & Definition & Source \\
\hline Scale economy & $\begin{array}{l}\text { Some studies have related to possible economies of scale, as } \\
\text { one of the motivations for Fintech to ally with Banks. }\end{array}$ & $\begin{array}{l}\text { Boot (2017) } \\
\text { Jakšič \& Marinc (2019) }\end{array}$ \\
\hline
\end{tabular}




\begin{tabular}{|l|l|l|}
\hline Category & Definition & Source \\
\hline Customers & $\begin{array}{l}\text { The "customers" factor materializes in the desire to respond to } \\
\text { new demands and value creation. }\end{array}$ & $\begin{array}{l}\text { Holotiuk, Klus, Lohwasser } \\
\text { \& Moormann (2018) } \\
\text { Walley (2007) }\end{array}$ \\
\hline
\end{tabular}

Source: Authors' own research

\section{Methodology}

The approach used is the Systematic Combining (Dubois \& Gadde, 2002), through a exploratory, qualitative analysis, using triangulation between information obtained through semi-structured interviews and secondary sources (News and relevant documentation).

The coopetitive partnerships established between Banks and Fintech, which have been referenced in the interviews, are analyzed; always resorting to the anonymity required in them. The collected information was encoded using the proposed theoretical framework (Table 1), but accepting emerging categories.

The sample of this research is theoretical and the selection process was based on the following criteria: 1) are ether or a bank or Fintech: 2) have already done a coopetitve alliance with (a) Banco/Fintech, 3) be active in Portugal.

The sample includes 9 banks and 9 Fintech. We also interviewed 2 supervisory institutions. In order to collect the necessary data interviews were conducted semi-structured interviews.

\section{Results and discussions}

\section{General Motivations}

The motivations for forming strategic alliances between competitors in general terms that were mentioned in the interviews are shown in Table 2, with the value representing the number of times each was mentioned during the interviews. A quote from the interviews that exemplifies this motivation is also presented.

Table 2 - Motivations in the formation of Strategic Alliances between competitors

\begin{tabular}{|c|c|c|c|}
\hline Motivation & Author (s) & Number & Examples \\
\hline $\begin{array}{l}\text { Access to new } \\
\text { markets or } \\
\text { market } \\
\text { segments }\end{array}$ & $\begin{array}{l}\text { Bengtsson \& } \\
\text { Kock }(2014) \\
\text { Raza-Ullah, } \\
\text { Bengtsson \& } \\
\text { Kock }(2014)\end{array}$ & 21 & $\begin{array}{l}\text { "(...) It is a win-win partnership, it is a partnership that is seen from } \\
\text { the side of Fintech as advantageous, too, for them, that is, they are } \\
\text { two players that, together, unite in order to conquer the market, in } \\
\text { order to conquer a market segment" (Bank A) }\end{array}$ \\
\hline $\begin{array}{ll}\text { Access } & \text { to } \\
\text { Resources } & \end{array}$ & $\begin{array}{l}\text { Bengtsson \& } \\
\text { Kock (2014) } \\
\text { Raza-Ullah, } \\
\text { Bengtsson \& } \\
\text { Kock }(2014)\end{array}$ & 53 & $\begin{array}{l}\text { "(...) the way it was impacting, fundamentally, is to cover areas } \\
\text { that we, today, were not covering, for example, in the case of } \\
\text { Artificial Intelligence, we did not have the skills, internally, yet... } \\
\text { we did not have, yet, the know- internal how and, therefore, } \\
\text { fundamentally allowed to accelerate this process" (Bank B) }\end{array}$ \\
\hline $\begin{array}{l}\text { Development } \\
\text { New Products } \\
\text { and New } \\
\text { Market } \\
\text { Standards }\end{array}$ & Radu (2010) & 43 & $\begin{array}{l}\text { "But, with this Bank, we have meetings... we are developing } \\
\text { specific products, but which can also be used and sold by other } \\
\text { institutions later, because the reality is common to many Banks } \\
\text { (...)" (Apiax) } \\
\text { "(...) We partnered with a Belgian company Edebex ... we decided } \\
\text { to launch an invoice discount product, we don't call it factoring, } \\
\text { because we don't have a factoring line, for the customer." (Bank } \\
\text { C) }\end{array}$ \\
\hline
\end{tabular}




\begin{tabular}{|c|c|c|c|}
\hline $\begin{array}{l}\text { Incorporate and } \\
\text { Develop New } \\
\text { Technologies }\end{array}$ & $\begin{array}{l}\text { Gnyawali \& } \\
\text { Park (2011) }\end{array}$ & 28 & $\begin{array}{l}\text { "(...) A bank does not have the capacity to carry out technological } \\
\text { development on its own, which is why, more and more (...) it has } \\
\text { to come from outside, because developing these pieces internally } \\
\text { is impossible." (Bank D) }\end{array}$ \\
\hline $\begin{array}{l}\text { Improve } \\
\text { position and } \\
\text { competitive } \\
\text { advantage }\end{array}$ & $\begin{array}{l}\text { Ritala (2012) } \\
\text { Ritala \& } \\
\text { Hurmelinna- } \\
\text { Laukkanen } \\
\text { (2009) } \\
\text { Rusko, (2011) } \\
\end{array}$ & 21 & $\begin{array}{l}\text { "(...) What benefits, for a Bank, large or small, that adopts a } \\
\text { collaborative model with a Fintech: (...) Banks gain reach, } \\
\text { visibility and reputation, by associating themselves with } \\
\text { innovative business models." (Bank E) }\end{array}$ \\
\hline $\begin{array}{l}\text { Knowledge } \\
\text { sharing }\end{array}$ & $\begin{array}{l}\text { Bengtsson \& } \\
\text { Kock (2014) } \\
\text { Raza-Ullah, } \\
\text { Bengtsson \& } \\
\text { Kock }(2014)\end{array}$ & 33 & $\begin{array}{l}\text { "(...) They contributed, with technical know-how, mainly, in these } \\
\text { components of digital certificates and biometric authentication } \\
\text { mechanisms and document validation mechanisms... we } \\
\text { contributed, a little, with what would be the business rules, the } \\
\text { contact with the Legislator and, in the end, try to make their } \\
\text { product commercial as well (...)" (Bank F) }\end{array}$ \\
\hline Risk Reduction & $\begin{array}{l}\text { Cygler, Sroka, } \\
\text { Solesvik, \& } \\
\text { Debkowska } \\
(2018)\end{array}$ & 16 & $\begin{array}{l}\text { "On the Banks side, what can they offer Fintech : (...) Experience } \\
\text { in risk management" (Bank E) }\end{array}$ \\
\hline $\begin{array}{l}\text { Willingness to } \\
\text { develop } \\
\text { Innovation }\end{array}$ & $\begin{array}{l}\text { Gast, Filser, } \\
\text { Gundolf \& } \\
\text { Kraus }(2015) \\
\text { Gnyawali \& } \\
\text { Park (2011) }\end{array}$ & 52 & $\begin{array}{l}\text { "I think that, more and more, they will be fundamental pieces, } \\
\text { because people have... Banks will have to accelerate the speed at } \\
\text { which they buy innovation (...) customers, more and more, are in } \\
\text { the channels and look for innovation, in the channels and banks do } \\
\text { not have this capacity, but they need to seek innovation from } \\
\text { suppliers, I think it is fundamental." (Bank D) }\end{array}$ \\
\hline
\end{tabular}

Source: Authors' own research

When analyzing the General Motivations most often mentioned in the interviews, the following stand out: Access to Resources, the Will to develop Innovation and the Development of New Products and New Market Standards. Access to resources is directly related to Coopetition strategies, so it is logical that it is the most mentioned category of Motivations; besides that, it is a motivation considered transversal to the various sectors of existing activities, due to its wide applicability in different markets or market segments. However, one of the possible outcomes of the coopetitive strategies analyzed in this study, Innovative Development, is materialized as the second motivation most mentioned, which, in a way, shows the innovation development as one of the main objectives in formation of strategic alliances between competitors. The third motivation that stands out is the Development of New Products and New Market Standards, which is also related to the establishment of strategic partnerships between competitors, since the combination of complementary resources, as a rule, aims to/or result, the creation of new products and/or new market standards.

\section{Specific motivations between Banks and Fintechs}

The motivations for the formation of strategic coopetitive alliances, specifically between Banks and Fintech that were indicated in the interviews are shown in Table 3. Both, banks and Fintechs, also referred the other party's motivation to establish a partnership, that might indicate that they are aware of the dynamics of all strategic partnership, and may indicate that they try understanding one to each other. 
Table 3 - Motivations in the formation of Strategic Alliances between Banks and Fintech

\begin{tabular}{|c|c|c|c|}
\hline \multicolumn{4}{|c|}{ Motivations (Banks ) } \\
\hline \multicolumn{4}{|c|}{ THEORETICAL CATEGORY } \\
\hline Motivation & Author (s) & $\begin{array}{l}\text { Number } \\
\text { of times }\end{array}$ & Examples \\
\hline $\begin{array}{l}\text { Scanning } \\
\text { Digital } \\
\text { innovation }\end{array}$ & $\begin{array}{l}\text { Klus, Lohwasser } \\
\& \text { Schwienbacher } \\
(2018) \\
\text { Holotiuk, Klus, } \\
\text { Lohwasser } \quad \& \\
\text { Moormann }(2018)\end{array}$ & 10 & $\begin{array}{l}\text { "(...) We were able to bring this innovation more quickly, and we } \\
\text { were able to help banking institutions in their digital } \\
\text { transformation processes (...)" (Infosistema) }\end{array}$ \\
\hline \multicolumn{4}{|c|}{ EMERGING CATEGORIES } \\
\hline Motivation & Number of times & & Examples \\
\hline Process Agility & 15 & $\begin{array}{l}\text { "I think th } \\
\text { compleme } \\
\text { agility in } \mathrm{p} \\
\text { of innovat }\end{array}$ & $\begin{array}{l}\text { ere are Fintechs, which are clearly positioning themselves to be } \\
\text { tary services, to be acquired, by the Banks; we are talking about } \\
\text { roduct creation and banks, even the best bank in the world, in terms } \\
\text { on, cannot guarantee it." (Bank C) }\end{array}$ \\
\hline $\begin{array}{l}\text { Fintech operate } \\
\text { in specific } \\
\text { niches }\end{array}$ & 12 & $\begin{array}{l}\text { "We are a } \\
\text { any real th } \\
\text { business } \\
\text { specializec } \\
\text { specializin } \\
\text { in granting }\end{array}$ & $\begin{array}{l}\text { so of the opinion that, currently, we have not yet witnessed, here, } \\
\text { reat from a Fintech, which will, therefore, shake the traditional } \\
\text { f Banking, because, if you notice, we have Fintech's very } \\
\text { in payments; Fintech's specialized in foreign exchange; Fintech's } \\
\text { in credit cards; Fintech's, some of which are already specialized } \\
\text { credit; but, we have none that covers all of these (...)" (Bank D) }\end{array}$ \\
\hline $\begin{array}{l}\text { Fintech } \\
\text { technological } \\
\text { know-how }\end{array}$ & 30 & $\begin{array}{l}\text { "(...) Our } \\
\text { they can } \\
\text { technologi } \\
\text { would allc } \\
\text { Bank G) }\end{array}$ & $\begin{array}{l}\text { partnership has been around these years because we believe that } \\
\text { give us the technological component, they could give us } \\
\text { cal development, they could give us a technological solution that } \\
\text { w us to provide better services to our customers." (Banco THE }\end{array}$ \\
\hline Reduce costs & 4 & $\begin{array}{l}\text { "(...) For } 1 \\
\text { that I just } \\
\text { much high }\end{array}$ & $\begin{array}{l}\text { his reason, we did this, in reality, if we wanted to apply everything } \\
\text { said, internally, we would have to have an investment capacity, } \\
\text { er than we have, than we would have (...)" (Bank C) }\end{array}$ \\
\hline $\begin{array}{l}\text { Resolution of } \\
\text { specific } \\
\text { problems in the } \\
\text { financial sector }\end{array}$ & 9 & $\begin{array}{l}\text { "In the cas } \\
\text { or the esta } \\
\text { of compet } \\
\text { can talk a } \\
\text { software d } \\
\text { have the b }\end{array}$ & $\begin{array}{l}\text { of private banking, we thought that we did not yet have products } \\
\text { lished name and, in addition, this segment is a segment with a lot } \\
\text { tion (...) so the first step was to create a digital platform }(. . .) \text { we } \\
\text { oout a partnership, with a Fintech (...) that supports Banks, in } \\
\text { evelopment, basically, from the Banks front-end, so that customers } \\
\text { st possible experience, in terms of user experience" (Bank C) }\end{array}$ \\
\hline
\end{tabular}

\begin{tabular}{|c|c|c|c|}
\hline \multicolumn{4}{|c|}{ Motivations (Fintech) } \\
\hline \multicolumn{3}{|c|}{ THEORETICAL CATEGORY } \\
\hline Motivation & Author (s) & $\begin{array}{l}\text { Number of } \\
\text { times }\end{array}$ & \multicolumn{1}{c|}{ Exemples } \\
\hline Scale economy & $\begin{array}{l}\text { Stewart \& } \\
\text { Jürjens , 2018 } \\
\text { Jakšič \& } \\
\text { Marinc (2019) }\end{array}$ & 5 & $\begin{array}{l}\text { "From this set, once again, the collaboration model allows: - } \\
\text { Scalability and access to global markets (...)" (Bank E) }\end{array}$ \\
\hline \multicolumn{3}{|c|}{ EMERGING CATEGORIES } \\
\hline Motivation & $\begin{array}{l}\text { Number of } \\
\text { times }\end{array}$ & \multicolumn{1}{|c|}{ Exemples } \\
\hline $\begin{array}{l}\text { Access to the } \\
\text { Bank's }\end{array}$ & 4 & $\begin{array}{l}\text { "On the Banks side, what can they offer Fintech : (...) - A broad customer base } \\
(\ldots) \text { " (Bank E) }\end{array}$ \\
\hline
\end{tabular}




\begin{tabular}{|c|c|c|c|}
\hline \multicolumn{4}{|l|}{$\begin{array}{l}\text { customer } \\
\text { portfolio }\end{array}$} \\
\hline $\begin{array}{l}\text { capital (Banks' } \\
\text { financial } \\
\text { capacity to } \\
\text { finance } \\
\text { technological } \\
\text { projects) }\end{array}$ & 2 & \multicolumn{2}{|c|}{$\begin{array}{l}\text { "(...) First, our focus on the Banking area is not an innocent focus... that is, } \\
\text { Fintech, I think they have a focus on the Banking area, first, because, once again, } \\
\text { as companies that are, they have money ... Even during the crisis and everything } \\
\text { else, a banking crisis that arose... Banks are companies that usually have money } \\
\text { to pay for projects, because you have to do new and different things (...) " } \\
\text { (Infosistema) }\end{array}$} \\
\hline $\begin{array}{l}\text { Customer Trust } \\
\text { (Credibility) }\end{array}$ & 5 & \multicolumn{2}{|c|}{$\begin{array}{l}\text { "The Bank offers the credibility that a Fintech does not yet have (...) a Fintech is } \\
\text { innovative, in itself }(\ldots) \text { but, afterwards, we need the credibility }(\ldots) \text { that the Bank } \\
\text { has" (Infosistema) }\end{array}$} \\
\hline $\begin{array}{l}\text { Market } \\
\text { knowledge of } \\
\text { banks }\end{array}$ & 7 & \multicolumn{2}{|c|}{$\begin{array}{l}\text { "(...) A Fintech is innovative, in itself (...) but, afterwards, we need (...) all the } \\
\text { market knowledge that Banking has.” (Trustpay Global) }\end{array}$} \\
\hline $\begin{array}{l}\text { Fill niches } \\
\text { where the } \\
\text { Banking is not } \\
\text { acting }\end{array}$ & 7 & \multicolumn{2}{|c|}{$\begin{array}{l}\text { "(...) A Fintech is innovative in itself, that is, it is flexible, it is looking for the } \\
\text { niche where the Banking is not acting (...)" (Trustpay Global) }\end{array}$} \\
\hline \multicolumn{4}{|c|}{ Common Motivation } \\
\hline Motivation & Author (s) & $\begin{array}{l}\text { Number } \\
\text { of times }\end{array}$ & Exemples \\
\hline Customers & $\begin{array}{l}\text { Holotiuk, } \\
\text { Klus, } \\
\text { Lohwasser \& } \\
\text { Moormann } \\
(2018) \\
\text { Walley } \\
(2007)\end{array}$ & 58 & $\begin{array}{l}\text { "(...) This is the second vector, which are new and different things, } \\
\text { that is, there is a growing demand, on the side of millenials, in terms } \\
\text { of what are the needs of the Banks, therefore, in terms of interface }(\ldots) \\
\text { And these partnerships (...) of Fintech, directly, with the Banks allow } \\
\text { a Fintech to suddenly have hundreds of thousands (...) of potential } \\
\text { customers, who will use technology and be different in these } \\
\text { customers' lives (...)" (Infosistema) } \\
\text { "(...) It is another partnership that we have, which was developed by } \\
\text { a company, a company which, after establishing a partnership with us, } \\
\text { gives us a service with added value, for the customer (..) knowing, at } \\
\text { the outset, that they are competitors but we have to look at them a lot } \\
\text { more, how do we get closer and have joint strategies, so that, together, } \\
\text { we can win the market." (Bank A) }\end{array}$ \\
\hline
\end{tabular}

Source: Authors' own research

By analyzing the Specific motivations, more often mentioned by banks, stand out: the know-how technological of the Fintech, their flexibility in the processes and the fact that Fintech operate in specific niches. The technological know-how that characterizes technological entities operating in the financial sector is currently one of the main gaps in banking institutions; which makes it logical that it is the main individual motivation of the Banks to establish strategic partnerships with these entities. In addition, this type of alliance makes it possible to fill, in various ways, the banks' lack of knowledge in technological areas, which makes it possible for them to respond to the current requirements of their customers. In the context of this sharing of technological knowledge, the agility in processes that Fintech allows, results in the second main motivation for banking institutions to join these entities. The current digitalization context 
promotes the need for quick answers to questions and problems that may arise from the use of banking services, and technological entities allow banks to respond, in a more agile way, to these requests from bank customers. Bank B claims that, in fact, coopetitive strategies represent the best way to establish partnerships, in this context, between Banks and Fintech. Finally, the third main motivation for Banks to ally themselves with Fintech is related to one of the characteristics that distinguish them: the fact that Fintech act, in their majority, in specific niches, being that they are mostly specialists in a certain segment of the banking business. This feature can also result in an advantage for the banks, as they can fill gaps in the most diverse sectors, in a more focused way, but without the Fintech could threaten the entire banking business.

On the side of Fintech after analysis of their own motivations, the most mentioned are: the knowledge of the market that the banks have, because they are considered incumbents in the sector; and the possibility of Fintechs fill in the niches where the dealer does not are you currently acting; namely, the niches related to gaps in new technologies, so that they can penetrate the financial market, by filling the needs of banking customers, which may not be being answered by banking institutions.

In conclusion, it should also be noted that the individual motivations, most often mentioned, by Banks and Fintech, are related to knowledge sharing; which is also one of the general motivations, most often mentioned, by both.

Through the analyzed results, a common component was identified for all the interviews carried out and present in most of the partnerships established between Banks and Fintech: the "customers" factor. The current situation, characterized by the emergence of new digital technologies, promotes greater concentration on the end customer and their requirements. As a rule, the banking business was characterized by traditional and static lines, however, the new digital context requires greater flexibility and agility in the processes, as well as a greater concern in adapting banking products and services to the customer; instead of the opposite strategy, which was, until now, the most used in the financial sector.

\section{Conclusion}

Coopetition strategies are being widely adopted and represent a means for the creation and development of innovation, however, there are still few studies that investigate the adoption of coopetitive strategies within the financial sector.

The present study presents the main motivations for Banks and Fintech to form coopetitive alliances, which are influenced by the individual characteristics of each type of entity; in addition to relating them to the possible collaboration models to be adopted; and the impact of these strategies on the type and intensity of innovation, so filling the gaps in literature relating to this topic.

Both Banks and Fintech have as their main motivation to create value for customers, responding to new demands, resulting from new digital technologies, with application in the financial sector; thus one of the main results of these alliances is the development of innovations. Due to the fact that it is a current topic and the discussion of its characteristics is open, several underlying themes can be explored in future investigations. Due to the complexity of this type of strategic partnerships, it is important to choose the ideal partner, especially when the main objective of the alliance is to develop innovation, therefore, this would be the first point of interest for future lines of research. In this study, the motivations for the formation of strategic alliances between Banks and Fintech are addressed, however, the importance of exploring the challenges or obstacles 
that result from this type of partnership is highlighted, and in addition to the individual characteristics being distinct, the way they approach the alliance influences their complex development, causing possible friction and difficulties.

\section{References}

Bengtsson, M., Johansson, M., Näsholm, M., \& Raza-Ullah, T. (2013). A systematic review of coopetition: levels and effects on different levels. Paper presented at the 13th Annual Conference of the European Academy of Management, EURAM 2013, 26-29 June 2013, Istanbul, Turkey.

Bengtsson, M., \& Kock, S. (2014). Coopetition-Quovadis? Past accomplishments and future challenges. Industrial Marketing Management, 43 (2), 180-188.

Bouncken, R., Clauß, T. \& Fredrich, V. (2016). Product innovation through coopetition in alliances: Singular or plural governance? Industrial Marketing Management, 53, 77-90.

Bouncken, R. \& Fredrich, V. (2016). Learning in coopetition: Alliance orientation, network size, and firm types. Journal of Business Research, 69 (5), 1753-1758.

Bouncken, R., Fredrich, V. \& Kraus, S. (2019).Configurations of Firm-level Value Capture in Coopetition. Long Range Planning.

Bouncken, R., Gast, J., Kraus, S., \& Bogers, M. (2015). Coopetition: a systematic review, synthesis, and future research directions. Review of Managerial Science, 9 (3), pp. 577-601.

Bouncken, R., \& Kraus, S. (2013). Innovation in knowledge-intensive industries: The double-edged sword of coopetition. Journal of Business Research, 66 (10), pp. 2060-2070.

Broek, J., Boselie, P. \& Paauwe, J. (2018). Cooperative innovation through a talent management pool: A qualitative study on coopetition in healthcare. European Management Journal, 36(1), 135-144.

Bussmann, O. (2017). The future of finance: FinTech, tech disruption, and orchestrating innovation. In Equity Markets in Transition: The Value Chain, Price Discovery, Regulation, and Beyond (pp. 473486): Springer International Publishing

Chiambaretto, P., Massé, D. \& Mirc, N. (2019). "All for One and One for All?" - Knowledge broker roles in managing tensions of internal coopetition: The Ubisoft case. Research Policy, 48(3), 584-600.

Cygler, J., Sroka, W., Solesvik, M., \& Dębkowska, K. (2018). Benefits and Drawbacks of Coopetition: The Roles of Scope and Durability in Coopetitive Relationships. Sustainability, 10(8).

Della Corte, V. \& Aria, M. (2016). Coopetition and sustainable competitive advantage. The case of tourist destinations. Tourism Management, 54, 524-540.

Dorn, S., Schweiger, B., \& Albers, S. (2016). Levels, phases and themes of coopetition: A systematic literature review and research agenda. European Management Journal, 34 (5), pp. 484-500.

Dubois, A. \& Gadde, L. (2002). Systematic Combining: An Abductive Approach to Case Research. Journal of Business Research. 55(7), 553-560.

Dvorsky, J., Petrakova, Z., \& Polach, J. (2019). Assessing the market, financial, and economic risk sources by Czech and Slovak SMEs. International Journal of Entrepreneurial Knowledge, 7(2), 30-40. 
Estrada, I., Faems, D., \& de Faria, P, (2016), Coopetition and product innovation performance: The role of internal knowledge sharing mechanisms and formal knowledge protection mechanisms. Industrial Marketing Management, 53, 56-65.

Gast, J., Filser, M., Gundolf, K. \& Kraus, S. (2015). Coopetition research: Towards a better understanding of past trends and future directions. International Journal of Entrepreneurship and Small Business, 24 (4), pp. 492-521.

PICBE | 292

Gnyawali, D. \& Park, B. (2011). Co-opetition between giants: Collaboration with competitors for technological innovation. Research Policy, 40 (5), pp. 650-663.

Gnyawali, D. \& Park, B. (2009). Co-opetition and technological innovation in small and medium-sized enterprises: A multilevel conceptual model. Journal of Small Business Management, 47 (3), pp. 308-330.

Holotiuk, F., Klus, M., Lohwasser, T. \& Moormann, J. (2018). Motives to Form Alliances for Digital Innovation: The Case of Banks and Fintechs. 31th Bled eConference: Digital Transformation Meeting the Challenges.

Jakšič, M. \& Marinc, M. (2019). Relationship Banking and Information Technology: The Role of Artificial Intelligence and Fintech. Risk Management. 21(1), 1-18.

Kawai, Y. (2016). FinTech. IAIS International Association of Insurance Supervisors, 53 (2).

Klimas, P. \& Czakon, W. (2018). Organizational innovativeness and coopetition: a study of video game developers. Review of Managerial Science. 12(2), 469-497.

Lee, K., Park, Y. \& Lee, D. (2017). Measuring efficiency and ICT ecosystem impact: Hardware vs. software industry. Telecommunications Policy. 42 (2).

Lee, I., \& Shin, Y. (2018). Fintech: Ecosystem, business models, investment decisions, and challenges. Business Horizons, 61 (1), pp. 35-46.

Luo, Y. (2005). Toward Coopetition within a Multinational Enterprise: A Perspective from Foreign Subsidiaries. Journal of World Business, 40 (1), pp. 71-90.

Radu, C. (2010). Need and potential risks of strategic alliances for competing successfully. Economy. Seria Management, 13 (1), 165-169

Raza-Ullah, T., Bengtsson, M. \& Kock, S. (2014). The coopetition paradox and tension in coopetition at multiple levels. Industrial Marketing Management, 43 (2), 189-198.

Ritala, P. (2012). Coopetition Strategy - When is it Successful? Empirical Evidence on Innovation and Market Performance. British Journal of Management, 23 (3), pp. 307-324.

Ritala, P. \& Hurmelinna-Laukkanen, P. (2009) What's in it for me? Creating and appropriating value in innovation-related coopetition, Technovation, 29 (12), 819-828

Romero, I., Porto-Gómez, I. \& Zabala-Iturriagagoitia, J. (2018). 'Cookpetition': Do restaurants coopete to innovate?. Tourism Economics

Rusko, R. (2011). Exploring the concept of coopetition: A typology for the strategic moves of the Finnish forest industry. Industrial Marketing Management, 40 (2), pp. 311-320.

DOI: $10.2478 /$ picbe-2020-0027, pp. 282-293, ISSN 2558-9652| Proceedings of the $14^{\text {th }}$ International Conference on Business Excellence 2020 
Schmidt, J., Drews, P. \& Schirmer, I. (2018). Charting the Emerging Financial Services Ecosystem of Fintechs and Banks: Six Types of Data-Driven Business Models in the Fintech Sector. Hawaii International Conference on System Sciences.

Stewart, H. \& Jürjens, J. (2018). Data security and consumer trust in FinTech Innovation in Germany. Information and Computer Security. 26 (1), pp. 109-12 8.

Walley, K. (2007). Coopetition: An Introduction to the Subject and an Agenda for Research. International Studies of Management \& Organization, 37, pp. 11-31.

Yami, S. \& Nemeh, A. (2014). Organizing coopetition for innovation: The case of wireless telecommunication sector in Europe. Industrial Marketing Management, 43 (2), pp. 250-260. 